\title{
Water availability limits tree productivity, carbon stocks, and carbon residence time in mature forests across the western US
}

\author{
Logan T. Berner ${ }^{1}$, Beverly E. Law ${ }^{1}$, and Tara W. Hudiburg ${ }^{2}$ \\ ${ }^{1}$ Department of Forest Ecosystems and Society, Oregon State University, 321 Richardson Hall, Corvallis, \\ Oregon, OR 97331-2212, USA \\ ${ }^{2}$ Department of Forest, Rangeland, and Fire Sciences, University of Idaho, 875 Perimeter Drive, Moscow, \\ Idaho, ID 83844-1133, USA
}

Correspondence to: Logan T. Berner (logan.berner@oregonstate.edu)

Received: 1 October 2016 - Published in Biogeosciences Discuss.: 5 October 2016

Revised: 26 December 2016 - Accepted: 9 January 2017 - Published: 24 January 2017

\begin{abstract}
Water availability constrains the structure and function of terrestrial ecosystems and is projected to change in many parts of the world over the coming century. We quantified the response of tree net primary productivity (NPP), live biomass (BIO), and mean carbon residence time $(\mathrm{CRT}=\mathrm{BIO} / \mathrm{NPP})$ to spatial variation in water availability in the western US. We used forest inventory measurements from 1953 mature stands (>100 years) in Washington, Oregon, and California (WAORCA) along with satellite and climate data sets covering the western US. We summarized forest structure and function in both domains along a $400 \mathrm{~cm} \mathrm{yr}^{-1}$ hydrologic gradient, quantified with a climate moisture index (CMI) based on the difference between precipitation and reference evapotranspiration summed over the water year (October-September) and then averaged annually from 1985 to $2014\left(\mathrm{CMI}_{\overline{\mathrm{wy}}}\right)$. Median NPP, BIO, and CRT computed at $10 \mathrm{~cm} \mathrm{yr}^{-1}$ intervals along the $\mathrm{CMI}_{\overline{\mathrm{wy}}}$ gradient increased monotonically with increasing $\mathrm{CMI}_{\overline{\mathrm{wy}}}$ across both WAORCA $\left(r_{\mathrm{S}}=0.93-0.96, p<0.001\right)$ and the western US $\left(r_{\mathrm{S}}=0.93-0.99, p<0.001\right)$. Field measurements from WAORCA showed that median NPP increased from 2.2 to $5.6 \mathrm{MgC} \mathrm{ha}^{-1} \mathrm{yr}^{-1}$ between the driest and wettest $5 \%$ of sites, while BIO increased from 26 to $281 \mathrm{MgCha}^{-1}$ and CRT increased from 11 to 49 years. The satellite data sets revealed similar changes over the western US, though these data sets tended to plateau in the wettest areas, suggesting that additional efforts are needed to better quantify NPP and BIO from satellites in high-productivity, high-biomass forests. Our results illustrate that long-term average water availability is a key environmental constraint on tree produc-
\end{abstract}

tivity, carbon storage, and carbon residence time in mature forests across the western US, underscoring the need to assess potential ecosystem response to projected warming and drying over the coming century.

\section{Introduction}

Water availability strongly constrains the distribution of plants on Earth's land surface (Holdridge, 1947; Major, 1963 ) and the resulting structure and function of terrestrial ecosystems (Churkina and Running, 1998; Law et al., 2002; Schuur, 2003). For instance, desert (Whittaker and Niering, 1975), grassland (Yang et al., 2008), and forest productivity (Law et al., 2002; Schuur, 2003; Berner and Law, 2015) differ widely among sites with contrasting water availability. Water availability is shaped by regional climate (e.g., precipitation, atmospheric evaporative demand), as well as by local topography and soils (Webb et al., 1983). Water availability is projected to change in many parts of the world over the coming century in response to continued atmospheric warming from sustained anthropogenic greenhouse gas emissions (Collins et al., 2013; Dai, 2013; Walsh et al., 2014). Societies depend on the goods and services provided by terrestrial ecosystems (e.g., forests; Williams, 2006) and thus it is imperative to elucidate climatic controls over ecosystem structure and function to help anticipate and mitigate potential impacts of ongoing climatic change.

The western US is a region where pronounced spatial variation in water availability exerts a strong influence over forest 
structure and function. For instance, average annual precipitation varies over $500 \mathrm{~cm} \mathrm{yr}^{-1}$ across this region, with particularly steep hydrologic gradients in the Pacific Northwest (Daly et al., 2008). Differences in water availability give rise to forest communities that range from dry, low-productivity woodlands to high-productivity coastal temperate rainforests where live-tree biomass (BIO) attains levels thought to be exceeded only by primary Eucalyptus regnans forests in southern Australia (Waring and Franklin, 1979; Keith et al., 2009).

Prior studies drew on small networks of field sites $(n<20)$ to investigate how tree net primary productivity (NPP) and BIO varied among mature stands spread along hydrologic gradients in parts of this region (Whittaker and Niering, 1975; Gholz, 1982; Webb et al., 1983; Berner and Law, 2015). Tree BIO and NPP can vary widely with stand age (Hudiburg et al., 2009) and thus these studies focused on mature stands (stand age generally $>100$ years) where BIO and NPP had somewhat stabilized after reaching their "climatic potential." These studies showed that BIO and NPP tended to increase linearly or curvilinearly across sites as average water availability increased (Whittaker and Niering, 1975; Gholz, 1982; Webb et al., 1983; Berner and Law, 2015). These spatial relationships are thought to reflect long-term climatic constraints on ecosystem structure (e.g., BIO) and function (e.g., NPP) that are shaped by gradual shifts in community composition and population size (Jin and Goulden, 2014). The field studies mentioned above make a compelling case that water availability is an important determinant of BIO and NPP in mature stands, yet these studies were based on a small number of field sites selected using a set of criteria (e.g., mature stands near a road) rather than on a large sample of mature stands in the region.

Several of these earlier field studies also indicated that plant communities accumulated more BIO per unit of NPP in progressively wetter areas, suggesting slower turnover of plant BIO as climate became wetter (Whittaker and Niering, 1975; Webb et al., 1983). Mean carbon residence time (CRT) describes the average duration that a carbon molecule will remain in a specific pool (Waring and Running, 2007), and for CRT in live biomass it can be computed as BIO / NPP, assuming that BIO remains constant over time (Whittaker, 1961; Friend et al., 2014). Carbon residence time in live biomass is also known as the biomass accumulation ratio (Whittaker, 1961) and ranged, for instance, from $\sim 2$ years in a hot desert shrubland to $\sim 75$ years in a wet, old-growth Douglas-fir forest (Webb et al., 1983). Differences in CRT among plant communities with contrasting climate are potentially associated with shifts in carbon allocation (e.g., short-lived fine roots and foliage vs. long-lived stem wood) and disturbance regimes (Girardin et al., 2010). Together, these field studies illustrate that forest structure and function are constrained by water availability in parts of the western US; however, additional efforts are needed to assess these relationships on larger scales across the region, particularly given that climate models project a pronounced shift towards hotter, drier con- ditions over much of the region during the coming century (Collins et al., 2013; Walsh et al., 2014; Cook et al., 2015).

Our objective in this study was to explore how forest structure and function change along spatial gradients in water availability across the western US. We used the average water-year climate moisture index $\left(\mathrm{CMI}_{\overline{\mathrm{wy}}} ; 1985-2014\right)$ as an indicator of long-term water availability (Webb et al., 1983; Hogg and Hurdle, 1995), which we computed as the cumulative difference between precipitation $(\mathrm{P})$ and reference evapotranspiration $\left(\mathrm{ET}_{0}\right)$ over the approximate seasonal cycle of soil water recharge and draw-down (OctoberSeptember). Furthermore, we focused on forest stands that were at least 100 years old because field surveys from the region indicated that BIO and NPP reached much of their climatic potential after a century. However, we acknowledge that BIO tends to gradually increase and NPP remains stable or gradually declines during subsequent centuries (Hudiburg et al., 2009). Building on prior field studies (e.g., Gholz, 1982; Webb et al., 1983; Berner and Law, 2015), we hypothesized that long-term water availability limits tree NPP, $\mathrm{BIO}$, and CRT in mature forest stands across the region. We thus predicted that tree NPP, BIO, and CRT in mature forests would increase with increasing $\mathrm{CMI}_{\overline{\mathrm{wy}}}$. Tree NPP, BIO, and CRT were based on above and belowground components. We tested these hypotheses first across Washington, Oregon, and California (WAORCA) using forest inventory measurements from 1953 sites and then across 18 Mha of mature forest in the western US using satellite remote sensing data sets. These data sets included three national biomass maps, along with NPP derived from the Moderate Resolution Imaging Spectroradiometer (MODIS). Forest inventories provide rigorous, though spatially limited, field measurements of forest structure and function, while satellite remote sensing provides spatially continuous, albeit modeled, estimates of forest structure and function across large domains.

\section{Materials and methods}

\subsection{Data sets and preprocessing}

\subsubsection{Field estimates of tree biomass, productivity, and carbon residence time}

We used field measurements to estimate tree BIO $\left(\mathrm{BIO}_{\text {field }}, \mathrm{MgCha}^{-1}\right)$, NPP (NPP field, $\mathrm{MgCha}^{-1} \mathrm{yr}^{-1}$ ), and CRT $\left(\mathrm{CRT}_{\text {field }}\right.$, year) at 1953 forest inventory sites located in mature stands spread across WAORCA (Table 1). These 1 ha sites were surveyed by the US Forest Service Forest Inventory and Analysis (FIA) program between 2001 and 2006 and comprise a representative sample of forest lands (tree cover $>10 \%$ ) in the region (Bechtold and Patterson, 2005). The inventory sites occurred at elevations ranging from 5 to $3504 \mathrm{~m}$, with an average $( \pm 1 \mathrm{SD})$ elevation of $1429 \pm 677 \mathrm{~m}$. We included sites in our analysis when stand age was at least 100 years. Stand age was defined as the av- 
erage age of the oldest $10 \%$ of trees, where individual tree age was determined at survey plots using increment cores (Van Tuyl et al., 2005). Tree $\mathrm{BIO}_{\text {field }}$ and $\mathrm{NPP}_{\text {field }}$ were computed for each site as part of a prior study (Hudiburg et al., 2011). Tree $\mathrm{BIO}_{\text {field }}$ was estimated using regional allometric equations for tree components (e.g., stem, branch, bark, foliage, and coarse roots) based on tree diameter and/or height (Means et al., 1994; Law et al., 2001), along with estimates of fine-root mass derived from a relationship with leaf area index (LAI, $\mathrm{m}^{2}$ leaf $\mathrm{m}^{-2}$ ground; Van Tuyl et al. 2005). Tree $\mathrm{NPP}_{\text {field }}$ was estimated based on changes in above and belowground woody biomass over a 10-year interval plus annual foliage and fine-root turnover. See Hudiburg et al. (2011) for additional details. We then computed $\mathrm{CRT}_{\text {field }}$ in live-tree biomass as the ratio of $\mathrm{BIO}_{\text {field }}$ to $\mathrm{NPP}_{\text {field. }}$

\subsubsection{Remote sensing estimates of tree biomass, productivity, and carbon residence time}

We used satellite remote sensing and ancillary data sets to estimate $\mathrm{BIO}\left(\mathrm{BIO}_{\text {sat }}\right), \mathrm{NPP}\left(\mathrm{NPP}_{\text {sat }}\right)$, and CRT $\left(\mathrm{CRT}_{\text {sat }}\right)$ across mature forests in the western US (Table 1). Tree $\mathrm{BIO}_{\text {sat }}$ included the same component carbon pools as $\mathrm{BIO}_{\text {field }}$ (i.e, stem, branch, bark, foliage, coarse roots, and fine roots). We quantified the amount of carbon in stems, branches, and bark using an ensemble of three satellite-derived data sets that depicted live-tree aboveground biomass (AGB, excluded foliage) circa 2000 to 2008 (Blackard et al., 2008; Kellndorfer et al., 2012; Wilson et al., 2013). Each map was generated using satellite and geophysical (e.g., climate, topography) data sets to spatially extrapolate forest inventory measurements over the conterminous US. We acquired these maps at $250 \mathrm{~m}$ spatial resolution and then converted two of the maps (Blackard et al., 2008; Kellndorfer et al., 2012) from dry biomass to carbon assuming a $50 \%$ conversion factor (Smith et al., 2006). We then reprojected these maps onto a uniform grid in an equal area projection, masked them to the common forest extent, and then averaged the AGB for each pixel across the three biomass maps. We used the biomass map ensemble average in the subsequent analysis, recognizing that pixel-wise estimates of AGB can vary notably among individual maps (Neeti and Kennedy, 2016).

After deriving spatial estimates of carbon storage in AGB, we then estimated carbon storage in coarse roots, fine roots, and foliage for each $250 \mathrm{~m}$ forested pixel. As with AGB, we assumed that roots and foliage were $50 \%$ carbon (Smith et al., 2006; Berner and Law, 2016). We computed coarseroot biomass based on an empirical relationship with AGB (Cairns et al., 1997) and fine-root biomass based on an empirical relationship with peak summer LAI (Van Tuyl et al., 2005). Spatial estimates of LAI were available globally at $1 \mathrm{~km}$ resolution from NASA's MODIS as part of the MOD15A2 (Collection 5) data set (Myneni et al., 2002). We obtained these LAI estimates at 8-day intervals during July and August (late summer) from 2000 to 2014 for the west- ern US. We then (1) excluded poor-quality pixels using the quality control flags, (2) computed average late-summer LAI over the 15-year period, and (3) reprojected and resampled the data set to the common $250 \mathrm{~m}$ resolution equal area grid. We used average late-summer MODIS LAI to compute both fine-root biomass (as described above) and foliage biomass. Foliage biomass was estimated for each pixel by dividing LAI by the average specific leaf area (SLA, $\mathrm{g} \mathrm{C} \mathrm{m}^{-2}$ leaf) of the forest type found in that pixel. We aggregated an existing map of forest type (Ruefenacht et al., 2008) into nine classes (e.g., Pinus ponderosa, true fir) and then varied SLA among classes using species-, genus-, or division-specific estimates of average SLA from a recent leaf trait synthesis (Berner and $\mathrm{Law}, 2016)$. We then estimated $\mathrm{BIO}_{\text {sat }}$ for each $250 \mathrm{~m}$ resolution pixel by summing the above and belowground carbon pools.

We quantified regional NPP using the satellite-derived MODIS primary productivity data set $\left(\mathrm{NPP}_{\text {sat }}, \mathrm{MOD} 17 \mathrm{~A} 3\right.$ v. 55). The MODIS light-use efficiency model predicts annual NPP at $1 \mathrm{~km}$ resolution across global terrestrial ecosystems by incorporating estimates of absorbed photosynthetically active radiation (APAR), LAI, and land cover derived from MODIS, together with plant physiological characteristics and climate data (Running et al., 2004; Zhao et al., 2010). The model first predicts daily gross primary productivity (GPP) based on APAR and the efficiency with which APAR is converted to biomass $(\varepsilon)$, which is affected by low temperatures (frost) and high vapor pressure deficit (VPD), inducing stomatal closure. The model then estimates plant respiration $(R)$ at daily-to-annual increments and subsequently computes annual NPP as the cumulative difference between GPP and $R$. These estimates thus reflect NPP allocated both above and belowground. We acknowledge a degree of circularity in relating $\mathrm{NPP}_{\text {sat }}$ to CMI given that both computations incorporate temperature data, specifically, temperature effects on VPD. We obtained annual NPP estimates from 2000 to 2014 for the western US, reprojected the data onto an equal area grid, and then averaged the data over years.

Several additional preprocessing steps were required after deriving forest $\mathrm{BIO}_{\text {sat }}$ and $\mathrm{NPP}_{\text {sat }}$. These included masking both $\mathrm{BIO}_{\text {sat }}$ and $\mathrm{NPP}_{\text {sat }}$ to areas mapped as forest by the MODIS land cover map (Friedl et al., 2010) and then further masking these data sets to include only areas where stand age was at least 100 years. The map of stand age reflected conditions around 2006 and was produced by Pan et al. (2011) by combining forest inventory measurements, information on historical fires, and optical satellite imagery. We applied these $1 \mathrm{~km}$ resolution masks to the $250 \mathrm{~m}$ resolution $\mathrm{BIO}_{\text {sat }}$ assuming homogenous land cover and stand age within each $1 \mathrm{~km}$ pixel. We then aggregated $\mathrm{BIO}_{\text {sat }}$ from $250 \mathrm{~m}$ to $1 \mathrm{~km}$ resolution and computed $\mathrm{CRT}_{\text {sat }}$ as the ratio of $\mathrm{BIO}_{\text {sat }}$ to $\mathrm{NPP}_{\text {sat }}$. 


\subsubsection{Climate data sets and derivation of the climate moisture index}

We quantified water availability using a climate moisture index (CMI) that was computed at monthly time steps as precipitation minus $\mathrm{ET}_{0}$ (Webb et al., 1983; Hogg, 1994). We summed monthly CMI over each water year (October in year $t-1$ to September in year $t$ ) from 1985 to 2014 and then averaged over the years to produce a 30 -year climatology $\left(\mathrm{CMI}_{\overline{\mathrm{wy}}}, \mathrm{cm} \mathrm{yr}^{-1}\right)$. The water year represents the approximate annual cycle of soil water recharge and withdrawal (Thomas et al., 2009). We obtained estimates of monthly precipitation from the Parameter-elevation Relationships on Independent Slopes Model (PRISM; Daly et al., 2008), which interpolated weather station measurements onto a $4 \mathrm{~km}$ resolution grid. We then estimated monthly $\mathrm{ET}_{0}$ using the Food and Agricultural Organizations (FAO) Penman-Monteith equation (FAO-56; Allen et al., 1998), where

$$
\mathrm{ET}_{0}=\frac{0.408 \Delta\left(R_{\mathrm{n}}-G\right)+\gamma\left(\frac{900}{T+273}\right) U\left(e_{\mathrm{s}}-e_{\mathrm{a}}\right)}{\Delta+\gamma(1+0.34 U)} .
$$

Variables included net incoming radiation $\left(R_{\mathrm{n}}\right)$, soil heat flux $(G)$, mean daily temperature $(T)$, wind speed $(U)$, and both saturation $\left(e_{\mathrm{s}}\right)$ and actual vapor pressure $\left(e_{\mathrm{a}}\right)$, as well as the psychrometric constant $(\gamma)$ and the slope of the vapor pressure curve $(\Delta)$. We quantified $R_{\mathrm{n}}$ and $U$ using monthly climatologies from the North American Land Data Assimilation System-2 (NALDAS-2, $\sim 12 \mathrm{~km}$ resolution) that were based on measurements from 1980 to 2009 (Mitchell et al., 2004). We derived $G, T, e_{\mathrm{s}}$, and $e_{\mathrm{a}}$ from PRISM temperature data following Zotarelli et al. (2010). We also computed $\mathrm{CMI}_{\overline{\mathrm{wy}}}$ based on $\mathrm{ET}_{0}$ derived using the modified Hargreaves approach (Hargreaves and Samani, 1985; Droogers and Allen, 2002) and found that our analysis was robust to differences in methods used to compute $\mathrm{ET}_{0}$ (results not shown). After computing $\mathrm{CMI}_{\overline{\mathrm{wy}}}$, we then resampled these data using the nearest neighbor approach to match the footprints of both the $1 \mathrm{~km} \mathrm{NPP}$ and $250 \mathrm{~m} \mathrm{BIO}$ remote sensing data sets.

\subsection{Analysis}

We quantified the response of tree NPP, BIO, and CRT to changes in $\mathrm{CMI}_{\overline{\mathrm{wy}}}$ across both WAORCA and the broader western US. We specifically focused on areas where $\mathrm{CMI}_{\overline{\mathrm{wy}}}$ was between -200 and $200 \mathrm{~cm} \mathrm{yr}^{-1}$, conditions which occurred both in WAORCA and in the broader region. This range encompassed $98 \%$ of forest area in the western US; the paucity of data in the remaining $2 \%$ of forest area that was either drier or wetter precluded rigorous analysis. We divided the landscape along this gradient into $10 \mathrm{~cm} \mathrm{yr}^{-1}$ nonoverlapping bins and then summarized forest characteristics in each bin by computing the median, along with the 10th, 25th, 75th, and 90th percentiles. Forest characteristics were summarized separately for the field and remote sensing data sets. There was a minimum of 10 and a maximum of 114 field sites in each bin. We then assessed the association between the median forest characteristic (i.e., NPP, BIO, and CRT) in each bin and $\mathrm{CMI}_{\overline{\mathrm{wy}}}$ across the bioclimatic gradient using nonparametric Spearman's rank correlation. This test yields a coefficient $\left(r_{\mathrm{s}}\right)$ between -1 and +1 , where a value of +1 indicates a perfect monotonically increasing relationship, a value of zero indicates no covariation between the two variables, and a value of -1 indicates a perfect monotonically decreasing relationship. The test is analogous to Pearson's correlation where the data were first ranked. We assessed the association between forest characteristics and $\mathrm{CMI}_{\overline{\mathrm{wy}}}$ using Spearman's correlation rather than nonlinear regression because our intent was to describe the general relationship rather than develop a predictive model. We performed data preprocessing, analysis, and visualization using ArcGIS 10 (ESRI, Redlands, CA) and Rstatistical software (R Core Team, 2015), relying extensively on the $R$ packages raster (Hijmans and van Etten, 2013) and dplyr (Wickham and Francois, 2015).

\section{Results}

Average annual water availability varied widely across both WAORCA and the broader western US from 1985 to 2014 (Fig. 1a, b). The $\mathrm{CMI}_{\overline{\mathrm{wy}}}$ ranged from a minimum of $-370 \mathrm{~cm} \mathrm{yr}^{-1}$ in southern California and Arizona to a maximum of $490 \mathrm{~cm} \mathrm{yr}^{-1}$ in the Olympic Mountains in northwestern Washington. Forests mapped by MODIS occurred in areas where $\mathrm{CMI}_{\overline{\mathrm{wy}}}$ was between -340 and $490 \mathrm{~cm} \mathrm{yr}^{-1}$, though $98 \%$ of forest area occurred between -200 and $200 \mathrm{~cm} \mathrm{yr}^{-1}$, and $72 \%$ occurred between -100 and $100 \mathrm{~cm} \mathrm{yr}^{-1}$. Average $( \pm 1 \mathrm{SD}) \mathrm{CMI}_{\overline{\mathrm{wy}}}$ in forested areas was $-40 \pm 80 \mathrm{~cm} \mathrm{yr}^{-1}$. The Coast Range and Cascade Mountains in Washington and Oregon were the wettest areas, with $\mathrm{CMI}_{\overline{\mathrm{wy}}}$ generally $>100 \mathrm{~cm} \mathrm{yr}^{-1}$. Water availability decreased rapidly in the rain shadows east of the Cascades and Sierra Nevada, giving rise to very steep $\mathrm{CMI}_{\overline{\mathrm{wy}}}$ gradients. For instance, annual $\mathrm{CMI}_{\overline{\mathrm{wy}}}$ in northern Oregon decreased nearly $350 \mathrm{~cm}$ over $\sim 30 \mathrm{~km}$ between high-elevation forests in the Cascades and low-elevation woodlands in the eastern foothills of the Cascades. The range in $\mathrm{CMI}_{\overline{\mathrm{wy}}}$ encountered along this gradient in the Cascades almost spanned the full range in $\mathrm{CMI}_{\overline{\mathrm{wy}}}$ that supported $98 \%$ of forest area in the western US. Dry forests occurred along the low-elevation margins of mountain ranges throughout continental areas, though the largest tract of dry forest was found in Arizona and New Mexico.

Tree NPP, BIO, and CRT varied substantially across both WAORCA and the broader western US in response to variation in $\mathrm{CMI}_{\overline{\mathrm{wy}}}$ (Figs. 1, 2; Table 2). We focused on forests in areas where $\mathrm{CMI}_{\overline{\mathrm{wy}}}$ was between -200 and $200 \mathrm{~cm} \mathrm{yr}^{-1}$, given the paucity of land and measurements in the $2 \%$ of forest area that was either drier or wetter. Median $\mathrm{NPP}_{\text {field }}$, 

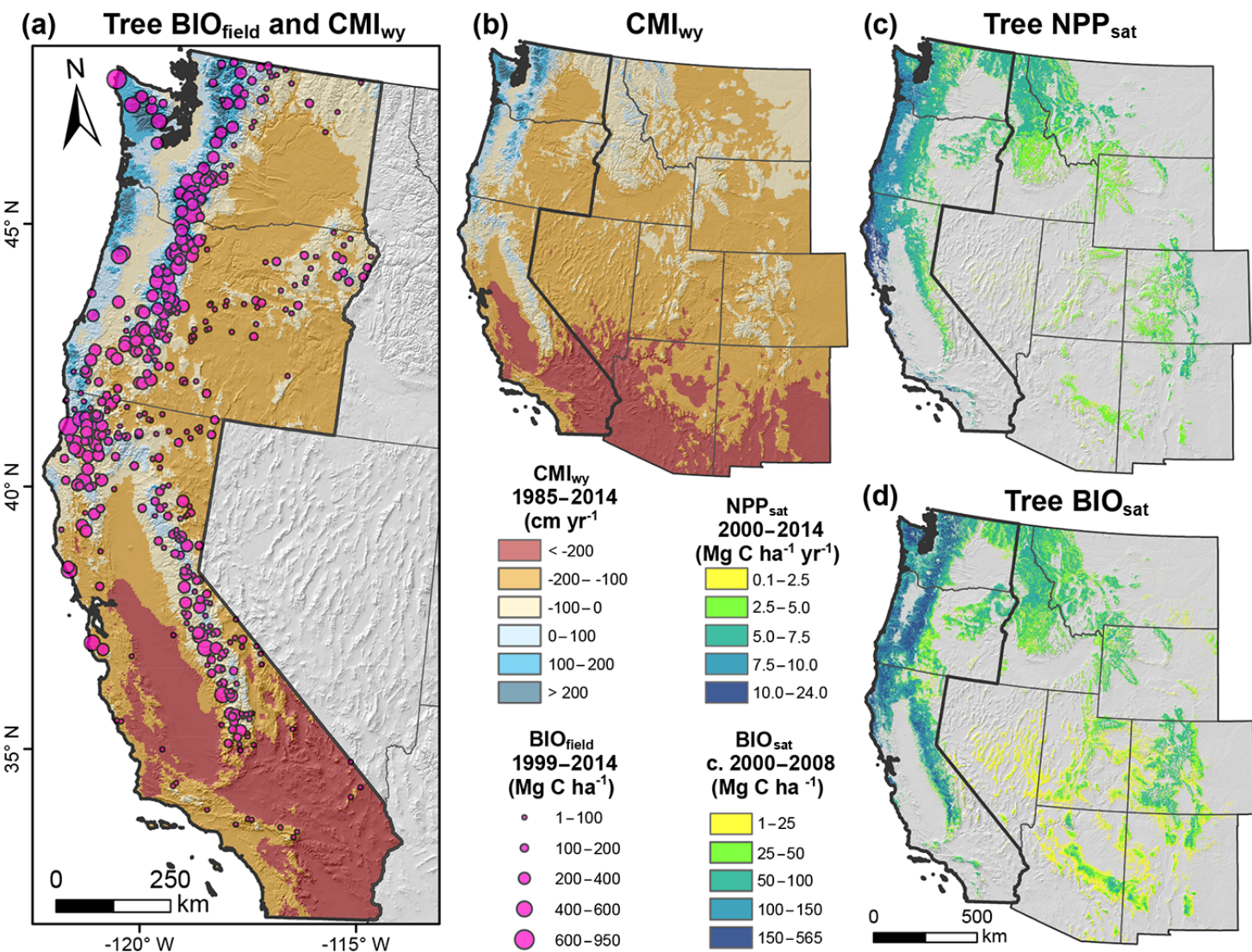

Figure 1. Mean climatic moisture index $\left(\mathrm{CMI}_{\overline{\mathrm{wy}}}, \mathrm{cm} \mathrm{yr}^{-1}\right)$, tree net primary productivity (NPP, $\left.\mathrm{MgCha}^{-1} \mathrm{yr}^{-1}\right)$, and live-tree biomass (BIO, $\mathrm{Mg} \mathrm{Cha}^{-1}$ ) in the western US. (a) Tree BIO derived from field measurements $\left(\mathrm{BIO}_{\text {field }}\right)$ at mature sites ( $>100$ years) in WAORCA. For visual clarity only $20 \%$ of the 1953 sites are depicted. (b) The $\mathrm{CMI}_{\overline{\mathrm{wy}}}$ was computed as monthly precipitation minus reference evapotranspiration summed over the annual water year (October-September) and then averaged from 1985 to 2014. (c) Mean annual NPP was quantified using MODIS satellite data from 2000 to 2014 (NPP sat). (d) Tree BIO was quantified using satellite-derived estimates of carbon stocks $\left(\mathrm{BIO}_{\text {sat }}\right)$.

Table 1. Summary of tree net primary productivity (NPP, $\mathrm{MgCha}^{-1} \mathrm{yr}^{-1}$ ), live biomass (BIO, $\mathrm{MgCha}^{-1}$ ), and carbon residence time (CRT, year) for stands over 100 years old across both WAORCA and the broader western US. These forest characteristics were quantified for WAORCA using field measurements from 1953 sites and for the western US using satellite-derived data sets covering 18 Mha of mature forest. Satellite data sets included MODIS NPP and an estimate of BIO derived by combining existing maps of aboveground biomass with additional estimates of carbon storage in coarse roots, fine roots, and foliage. These carbon stocks and fluxes combine above and belowground components.

\begin{tabular}{lllrrr}
\hline Domain & Variable & Units & Time span & Mean (SD) & Range \\
\hline \multirow{2}{*}{ WAORCA } & $\mathrm{NPP}_{\text {field }}$ & $\mathrm{Mg} \mathrm{Cha}^{-1} \mathrm{yr}^{-1}$ & $2001-2006$ & $4.3(2.5)$ & $0.6-20.9$ \\
& $\mathrm{BIO}_{\text {field }}$ & $\mathrm{Mg} \mathrm{Cha}^{-1}$ & $2001-2006$ & $158(135)$ & $2-947$ \\
& $\mathrm{CRT}_{\text {field }}$ & year & $2001-2006$ & $33(19)$ & $2-137$ \\
\multirow{2}{*}{ Western US } & $\mathrm{NPP}_{\text {sat }}$ & $\mathrm{Mg} \mathrm{Cha}^{-1} \mathrm{yr}^{-1}$ & $2000-2014$ & $5.3(2.0)$ & $0.1-22.7$ \\
& $\mathrm{BIO}_{\text {sat }}$ & $\mathrm{Mg} \mathrm{Cha}^{-1}$ & $2000-2008$ & $83(54)$ & $2-669$ \\
& $\mathrm{CRT}_{\text {sat }}$ & year & $2000-2008$ & $15(9)$ & $2-1390$ \\
\hline
\end{tabular}

$\mathrm{BIO}_{\text {field, }}$ and $\mathrm{CRT}_{\text {field }}$ all exhibited a strong, positive association with $\mathrm{CMI}_{\overline{\mathrm{wy}}}\left(r_{\mathrm{s}}=0.93-0.96, p<0.001\right)$. Median $\mathrm{NPP}_{\text {field }}$ increased $155 \%$ between the driest and wettest $5 \%$ of sites in WAORCA (Fig. 2a), while median $\mathrm{BIO}_{\text {field }}$ and $\mathrm{CRT}_{\text {field }}$ increased 997 and $358 \%$, respectively, between these sites (Fig. 2b, c; Table 2). The relationship in each case was slightly curvilinear. There were also strong, positive relationships among median $\mathrm{NPP}_{\text {field }}, \mathrm{BIO}_{\text {field }}$, and $\mathrm{CRT}_{\text {field }}$ 

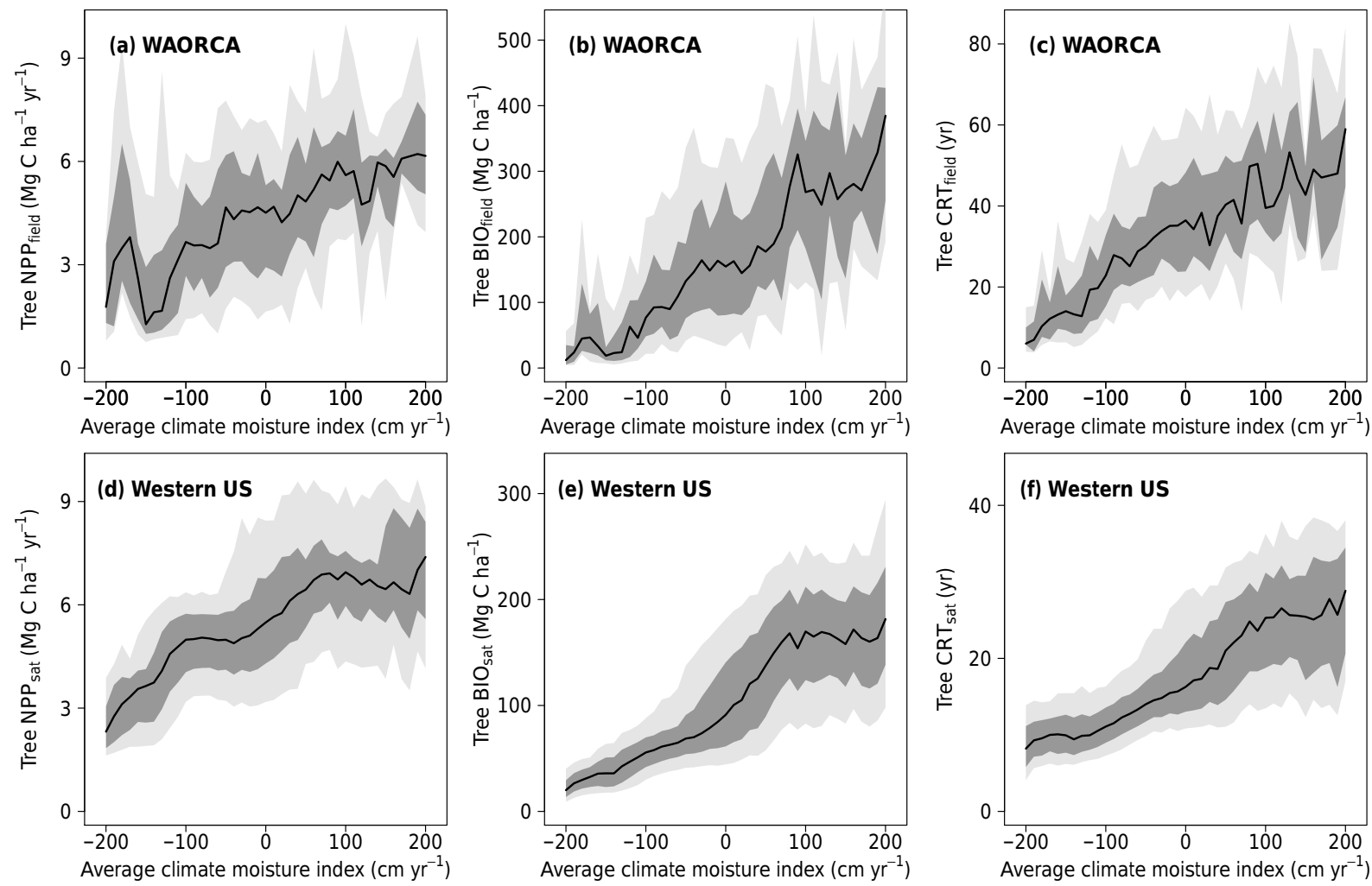

Figure 2. Tree net primary productivity (NPP, $\mathrm{MgCha}^{-1} \mathrm{yr}^{-1}$ ), live biomass (BIO, $\mathrm{MgCha}^{-1}$ ), and carbon residence time (CRT, years) increased with increasing water availability across both WAORCA (a-c) and the broader western US (d-f). Forest characteristics were derived from field measurements at 1953 inventory plots in WAORCA $(\mathbf{a}-\mathbf{c})$ and from satellite remote sensing data sets across 18 Mha of mature forest in the western US (d-f). Tree NPP sat was characterized using MODIS data averaged annually from 2000 to 2014 . Tree BIO sat $_{\text {was quantified }}$ based on an ensemble of aboveground biomass maps plus estimates of coarse-root, fine-root, and foliage biomass. Tree CRT was computed for each field plot and pixel as BIO/NPP. Water availability was quantified using a climate moisture index $\left(\mathrm{CMI}=P-\mathrm{ET}_{0}\right)$ summed over the water year (October-September) and then averaged from 1985 to $2014\left(\mathrm{CMI}_{\overline{\mathrm{wy}}}\right)$. The region was partitioned into $10 \mathrm{~cm} \mathrm{rr}^{-1}$ (nonoverlapping) $\mathrm{CMI}_{\overline{\mathrm{wy}}}$ bins, pixels and plots were allocated to bins, and then forest characteristics were summarized within each bin. In each panel, the bold line denotes the median, the dark gray band the $25-75$ th percentiles, and the light gray band the 10-90th percentiles. Note the different $y$ axis scales between (b) and (e), as well as (c) and (f).

Table 2. Changes in tree net primary productivity ( $\mathrm{NPP}, \mathrm{Mg} \mathrm{Cha}^{-1} \mathrm{yr}^{-1}$ ), live biomass (BIO, $\mathrm{Mg} \mathrm{C}^{-1}$ ), and carbon residence time (CRT, year) for stands over 100 years old along gradients in a climate moisture index $\left(\mathrm{CMI}_{\overline{\mathrm{wy}}}, \mathrm{cm} \mathrm{yr}^{-1}\right)$ in both WAORCA and the broader western US. Forest characteristics were quantified using field measurements in WAORCA and satellite remote sensing data sets covering the western US. The analysis incorporated forests in areas where $\mathrm{CMI}_{\overline{\mathrm{wy}}}$ was between -200 and $200 \mathrm{~cm} \mathrm{yr}^{-1}$. Summaries include $(1)$ median forest characteristics in the driest $5 \%$ and wettest $95 \%$ of pixels or plots, (2) the corresponding change, and (3) Spearman's correlation $\left(r_{\mathrm{s}}\right)$ between $\mathrm{CMI}_{\overline{\mathrm{wy}}}$ and the median forest characteristics computed at $10 \mathrm{~cm} \mathrm{yr}^{-1} \mathrm{CMI}_{\overline{\mathrm{wy}}}$ intervals. All correlations were statistically significant at $\alpha<0.001$.

\begin{tabular}{cllrrrrr}
\hline \multirow{2}{*}{ Domain } & Variable & \multirow{2}{*}{ Units } & \multicolumn{2}{c}{ Median of... } & \multicolumn{2}{c}{ Change... } & $\mathrm{CMI}_{\overline{\mathrm{wy}}}$ cor. \\
\cline { 3 - 7 } & & & Driest 5\% & Wettest 95 \% & Abs. & $\%$ & $r_{\mathrm{s}}$ \\
\hline \multirow{2}{*}{ WAORCA } & $\mathrm{NPP}_{\text {field }}$ & $\mathrm{Mg} \mathrm{Cha}^{-1} \mathrm{yr}^{-1}$ & 2.2 & 5.6 & 3.4 & 155 & 0.93 \\
& $\mathrm{BIO}_{\text {field }}$ & $\mathrm{Mg} \mathrm{Cha}^{-1}$ & 26 & 281 & 255 & 997 & 0.96 \\
\multirow{3}{*}{ Western US } & $\mathrm{CRT}_{\text {field }}$ & year & 11 & 49 & 38 & 358 & 0.96 \\
& $\mathrm{NPP}_{\text {sat }}$ & $\mathrm{Mg} \mathrm{Cha}^{-1} \mathrm{yr}^{-1}$ & 3.4 & 6.7 & 3.3 & 97 & 0.93 \\
& $\mathrm{BIO}_{\text {sat }}$ & $\mathrm{Mg} \mathrm{Cha}^{-1}$ & 32 & 165 & 133 & 410 & 0.97 \\
& $\mathrm{CRT}_{\text {sat }}$ & year & 10 & 26 & 16 & 160 & 0.99 \\
\hline
\end{tabular}


along the WAORCA bioclimatic gradient $\left(r_{\mathrm{s}}=0.90-0.96\right.$, $p<0.001$ ).

Broadly similar patterns were evident when tree $\mathrm{NPP}_{\text {sat }}$, $\mathrm{BIO}_{\text {sat }}$, and $\mathrm{CRT}_{\text {sat }}$ were examined across the western US using remote sensing data sets (Figs. 1b-d, 2c, d; Table 2). Median $\mathrm{NPP}_{\text {sat }}, \mathrm{BIO}_{\text {sat }}$, and CRT $\mathrm{Cat}_{\text {sat }}$ all showed a strong, positive relationship with $\mathrm{CMI}_{\overline{\mathrm{wy}}}\left(r_{\mathrm{s}}=0.93-0.99, p<0.001\right)$. Median NPP $\mathrm{Nat}_{\text {sat }}$ increased $97 \%$ between the driest and wettest $5 \%$ of forested areas along the regional $\mathrm{CMI}_{\overline{\mathrm{wy}}}$ gradient (Fig. 2d, Table 2). Similarly, median $\mathrm{BIO}_{\text {sat }}$ and $\mathrm{CRT}_{\text {sat }}$ increased 410 and $160 \%$, respectively, between the driest and wettest areas (Fig. 2e, f; Table 2). The response of median $\mathrm{NPP}_{\text {sat }}, \mathrm{BIO}_{\text {sat }}$, and $\mathrm{CRT}_{\text {sat }}$ to increased $\mathrm{CMI}_{\overline{\mathrm{wy}}}$ was more curvilinear than the field measurements and plateaued in areas where $\mathrm{CMI}_{\overline{\mathrm{wy}}}$ exceeded $\sim 100 \mathrm{~cm} \mathrm{yr}^{-1}$. Furthermore, while magnitude of $\mathrm{NPP}_{\text {sat }}$ and $\mathrm{NPP}_{\text {field }}$ response to $\mathrm{CMI}_{\overline{\mathrm{wy}}}$ were similar, the magnitude of $\mathrm{BIO}_{\text {sat }}$ and $\mathrm{CRT}_{\text {sat }}$ responses to increased $\mathrm{CMI}_{\overline{\mathrm{wy}}}$ were much more muted than the magnitude of response in $\mathrm{BIO}_{\text {field }}$ and $\mathrm{CRT}_{\text {field }}$. Nevertheless, fieldand satellite-derived estimates of median NPP, BIO, and CRT were strongly correlated $\left(r_{\mathrm{S}}=0.90-0.95, p<0.001\right)$.

Furthermore, there were again strong relationships among median $\mathrm{NPP}_{\text {sat }}, \mathrm{BIO}_{\text {sat }}$, and $\mathrm{CRT}_{\text {sat }}$ along the western US bioclimatic gradient $\left(r_{\mathrm{s}}=0.93-0.97, p<0.001\right)$.

\section{Discussion and conclusions}

\subsection{Climate moisture index}

Water availability exerted a strong influence on tree NPP, $\mathrm{BIO}$, and CRT among mature forests in the western US. We chose to quantify water availability using an index that accounted for both precipitation and energy-mediated $\mathrm{ET}_{0}$, recognizing that both of these factors contribute to the relative water stress experienced by plants within an ecosystem (Webb et al., 1983). We acknowledge that this index has several shortcomings. For instance, the index does not account for spatial variation in soil water storage capacity, which can be crucial for determining plant performance during drought (Peterman et al., 2013). This might explain some of the variation in NPP and BIO among areas with similar $\mathrm{CMI}_{\overline{\mathrm{wy}}}$; however, quantifying soil water storage capacity even at individual sites is challenging given uncertainty in soil structure and plant rooting capacity (Running, 1994). The index also does not account for water added via fog drip, which has been shown to supply $13-45 \%$ of the water transpired by redwood forests (Sequoia sempervirens) (Dawson, 1998) and sustain other forest ecosystems along the California coast (Johnstone and Dawson, 2010; Fischer et al., 2016). This potentially explains why there were areas with low $\mathrm{CMI}_{\overline{\mathrm{wy}}}$ along the central and northern coast of California that supported forests with higher NPP and BIO than other forests with similar $\mathrm{CMI}_{\overline{\mathrm{wy}}}$. Furthermore, the index does not account for spatial variation in runoff and thus likely overestimates water availability in the wettest areas since the fraction of water lost as runoff increases with precipitation (Sanford and Selnick, 2013). Despite its relative simplicity, prior studies showed that CMI was a useful index for explaining interannual variability in fire activity in the southwestern US (Williams et al., 2014), as well as forest productivity in northern Siberia (Berner et al., 2013), southern Canada (Hogg et al., 2002), and central Oregon (Berner and Law, 2015). Several studies also found that the index, or its inverse (i.e., $\mathrm{ET}_{0}-P$ ), explained substantial spatial variability in mature forest gross photosynthesis (Law et al., 2002), productivity, and biomass across a range of ecosystems (Webb et al., 1983; Hogg et al., 2008; Berner and Law, 2015). Our current study further demonstrates that CMI is a useful empirical index for assessing climatic constraints on forest ecosystems on large spatial scales.

\subsection{Tree net primary productivity}

Median tree NPP in mature stands approximately doubled between the driest and wettest areas in both WAORCA and the western US, though in both cases the rate at which NPP increased with $\mathrm{CMI}_{\overline{\mathrm{wy}}}$ slowed in the wettest areas. Prior field studies conducted at a limited number of field sites in the western US over the past 4 decades have similarly documented increased tree NPP along spatial gradients of increasing water availability (Whittaker and Niering, 1975; Gholz, 1982; Webb et al., 1983; Berner and Law, 2015). Building on these prior efforts, our current study demonstrates a robust relationship between tree NPP and water availability in mature forests using field measurements from nearly 2000 inventory plots along with satellite remote sensing estimates of NPP covering $\sim 18$ Mha of forestland.

The NPP-CMI $I_{\overline{w y}}$ relationship was similar when NPP was assessed using field measurements from across WAORCA or using MODIS covering the western US. The NPP estimates derived from MODIS did level off in the wettest parts of WAORCA $\left(\mathrm{CMI}_{\overline{\mathrm{wy}}} \approx 100-200 \mathrm{~cm} \mathrm{yr}^{-1}\right)$, whereas this was less evident in the field measurements. The inventory sites and MODIS forestland occurred at similar elevations along the $\mathrm{CMI}_{\overline{\mathrm{Wy}}}$ gradient in WAORCA, suggesting that this discrepancy in NPP was not due to MODIS systematically including cold, high-elevation areas not sampled by the inventory sites. One possibility is that MODIS NPP did not increase in the wettest areas because MODIS becomes less sensitive to increases in the fraction of photosynthetically active radiation (FPAR) absorbed by plant canopies in densely vegetated areas (Yan et al., 2016). A recent MODIS analysis similarly found that the amount of photosynthetically active radiation absorbed by plant canopies (APAR $=$ FPAR $\times$ PAR) increased asymptotically with increasing mean annual precipitation across plant communities in California (Jin and Goulden, 2014). Forests had higher APAR than other plant communities and, furthermore, exhibited the smallest increase in APAR per unit increase in precipitation of any plant community, suggesting that forest productivity was less sen- 
sitive to changes in precipitation than productivity of other plant communities (Jin and Goulden, 2014). In contrast with the field measurements, the asymptotic response of MODIS NPP and APAR to increasing water availability in wet areas suggests that climate impact assessments based on MODIS could underestimate the sensitivity of plant productivity to changes in water availability in wet areas with high biomass.

Mechanistically, the strong NPP-CMI $\mathrm{Wy}_{\overline{\mathrm{wy}}}$ association reflects the coupling between carbon and water cycling at leaf (Ball et al., 1987)-to-ecosystem scales (Law et al., 2002). Tree NPP depends on regionally specific relations with leaf area (Schroeder et al., 1982; Waring, 1983), which largely determine the proportion of incoming solar radiation that is absorbed and thus potentially available to fuel photosynthesis (Runyon et al., 1994). Leaf photosynthesis inevitably leads to transpiration water loss (Ball et al., 1987) that must be balanced against water uptake from the soil so as to prevent the formation of excessive tension on the internal water column, which could result in hydraulic failure (Williams et al., 1996; Ruehr et al., 2014). As soil water availability increases, trees are able to support greater leaf area while maintaining water column tensions within physiologically operable ranges, which consequently leads to more photosynthate available to fuel NPP, unless trees are limited by other resources (e.g., nitrogen). The decreasing rate at which NPP increased with $\mathrm{CMI}_{\overline{\mathrm{wy}}}$ in the wettest areas is likely due to low temperatures constraining productivity at high elevations (Runyon et al., 1994; Nakawatase and Peterson, 2006) and heavy cloud cover limiting solar radiation and thus photosynthesis in coastal areas (Zhao et al., 2010; Carroll et al., 2014). Tree NPP is affected by many biotic (e.g., age) and abiotic factors (e.g., nutrients), yet water availability emerges as a key environmental constraint in the western US.

\subsection{Tree carbon stocks}

Tree BIO increased notably with increasing $\mathrm{CMI}_{\overline{\mathrm{wy}}}$ in mature forests across both WAORCA and the broader western US, reflecting underlying shifts in NPP and, likely, BIO mortality rates due to natural disturbance. Tree biomass is determined by the rates at which carbon is gained via NPP and lost due to tissue senescence and mortality integrated over annual to centennial timescales (Olson, 1963). Hence, the increase in NPP with increasing $\mathrm{CMI}_{\overline{\mathrm{wy}}}$ explains some of the concomitant increase in BIO. Our analysis did not investigate how tissue senescence or mortality varied along the regional bioclimatic gradient, though a recent study found that BIO mortality rates due to bark beetles and fires were very low in the wettest parts of the western US (e.g., Coast Range and Cascades), while considerably higher in most drier areas (Hicke et al., 2013). Furthermore, the field and satellite data sets also incidentally revealed that there was an increase in the median age of stands over 100 years as conditions became wetter, with median stand age at $\sim 140$ years in the driest areas and 200-240 years in the wettest areas. The general increase in
BIO with increasing water availability is thus likely due to higher rates of productivity and potentially lower BIO mortality rates from natural disturbance.

The observed increase in BIO with increasing water availability was generally consistent with prior field studies from this region, yet our study demonstrates this response over a much broader bioclimatic gradient. For instance, early work by Whittaker and Niering (1975) showed that BIO in mature forests tended to increase with a moisture index inferred from community composition along an elevational gradient in Arizona's Santa Catalina Mountains. Subsequent studies, focused on five long-term ecological research (LTER) sites spread across the conterminous US (Webb et al., 1983) and at 8-12 sites in Oregon (Gholz, 1982; Berner and Law, 2015), similarly showed a general increase in tree biomass with increasing water availability. Our study included sites that ranged from dry woodlands with little BIO to temperate rainforests with $\mathrm{BIO}$ exceeded in few other regions (e.g., max $\mathrm{BIO} \approx 950 \mathrm{Mg} \mathrm{Cha}^{-1}$ ). Tree biomass in our study area has been reported to reach over $2000 \mathrm{MgCha}^{-1}$ in old-growth coastal redwood stands in northern California (Waring and Franklin, 1979), which is thought to be exceeded only by the $>3000 \mathrm{MgC} \mathrm{ha}^{-1}$ attained by old-growth Eucalyptus regnans stands in southern Australia (Keith et al., 2009). A global synthesis suggested that average AGB among highbiomass stands in wet temperate forests $\left(\sim 377 \mathrm{MgC} \mathrm{ha}^{-1}\right)$ was over 2 times that of high-biomass stands in wet tropical forests $\left(\sim 179 \mathrm{MgCha}^{-1}\right)$ and nearly 6 times that of high-biomass stands in wet boreal forests $\left(\sim 64 \mathrm{Mg} \mathrm{Cha}^{-1}\right)$ (Keith et al., 2009). The range in BIO included in our analysis of WAORCA thus spanned much of the observed global range in BIO.

Both field and satellite measurements revealed that median BIO increased with $\mathrm{CMI}_{\overline{\mathrm{Wy}}}$, yet the satellite data set showed less of an increase than the field measurements. Median forest $\mathrm{BIO}_{\text {field }}$ increased nearly $1000 \%$ between the dry woodlands and coastal temperate rainforests in WAORCA, yet the increase in $\mathrm{BIO}_{\text {sat }}$ with increasing $\mathrm{CMI}_{\overline{\mathrm{wy}}}$ was less pronounced $(\sim 410 \%$ increase) when assessed across the western US. Furthermore, median $\mathrm{BIO}_{\text {sat }}$ plateaued around $175 \mathrm{MgCha}^{-1}$ in areas where $\mathrm{CMI}_{\overline{\mathrm{wy}}}$ was $\sim 100$ $200 \mathrm{~cm} \mathrm{yr}^{-1}$. The response of BIO to increasing $\mathrm{CMI}_{\overline{\mathrm{wy}}}$ was likely more muted when assessed using the satellite-derived maps than the field measurements for several reasons. The maps are largely derived from optical, multispectral satellite imagery that is not very sensitive to variation in BIO in highbiomass forests. Additionally, areas with high BIO often occur as small patches set in a matrix of stands with lower BIO (Spies et al., 1994) and thus the moderate-resolution satellite imagery used in developing these maps records the spectral signature of this larger area rather than just the patch with high BIO. In other words, the satellite imagery has a larger sampling footprint relative to that of a field plot, which thus averages BIO over a larger area, reducing peak values. Advances in satellite remote sensing, such as NASA's new 
Global Ecosystem Dynamics Investigation Lidar (GEDI) instrument, are anticipated to help overcome some of these challenges (Goetz and Dubayah, 2011). Nevertheless, current BIO maps (e.g., Kellndorfer et al., 2012; Wilson et al., 2013) proved to be valuable tools for ecologic and natural resource assessments (Berner et al., 2012; Goetz et al., 2014; Krankina et al., 2014).

\subsection{Carbon residence time in tree biomass}

We computed CRT as BIO/NPP and found that median $\mathrm{CRT}_{\text {field }}$ increased persistently with $\mathrm{CMI}_{\overline{\mathrm{wy}}}$ from $\sim 11$ years in the driest forests to over 49 years in the wettest forests, highlighting a fundamental change in ecosystem function along this broad bioclimatic gradient. One limitation of our study is that computing CRT in this manner assumes that $\mathrm{BIO}$ is constant over time (Friend et al., 2014). We focused on mature stands ( $>100$ years) to minimize the change in BIO over time, though we acknowledge that BIO can gradually increase during subsequent centuries (Hudiburg et al., 2009), which would lead to underestimated CRT. Conversely, drought and insect-induced defoliation in the early 2000s could have suppressed NPP (Schwalm et al., 2012; Berner and Law, 2015) without a proportional reduction in BIO, which could have inflated our estimates of CRT in some areas. Nevertheless, our results agree well with a prior study focused on 11 long-term ecological research sites (LTERSs) spread across the conterminous US that found that CRT increased from $\sim 2$ years in a desert shrubland to $\sim 73$ years in a 450-year-old Douglas-fir stand at the Andrews LTER in the Cascade Mountains in Oregon (Webb et al., 1983). For comparison, we looked at five old-growth Douglas-fir stands (336-555 years old) near the Andrews LTER and found that $\mathrm{CRT}_{\text {field }}$ averaged $79 \pm 23$ years $( \pm 1 \mathrm{SD})$ among these stands. An increase in the CRT of aboveground tissues was also observed among plant communities along an elevational moisture gradient in the Santa Catalina Mountains of Arizona (Whittaker and Niering, 1975) and across nine mature stands in a range of forest communities in Oregon (Gholz, 1982). Although this pattern has been previously documented on small scales, the underlying mechanisms remain unclear.

We speculate that the increase in CRT with increased water availability was associated with underlying changes in NPP allocation, BIO mortality rates, and stand age. Trees invest a larger proportion of NPP into aboveground tissue production as conditions become wetter and competition for light intensifies (Runyon et al., 1994; Law et al., 2003). Our field measurements suggested that the fraction of NPP allocated aboveground increased from $\sim 0.45$ in the driest areas to $\sim 0.64$ in the wettest areas and, furthermore, that CRT in aboveground tissues averaged twice as long as CRT in belowground tissues. Thus, a shift in NPP allocation toward longerlived aboveground tissues likely contributed to longer CRT in wetter areas. Longer CRT in wetter areas could also be re- lated to forests in these areas (e.g., Coast Range) experiencing lower BIO mortality rates from wildfire and bark beetles than forests in drier, continental areas (Hicke et al., 2013). We also found that mature stands tended to be older in wetter areas and that older stands tended to have longer CRT, likely as a result of these stands having higher BIO and similar NPP (Hudiburg et al., 2009). Consequently, the CRT-CMI $\overline{\text { wy }}$ relationships that we observed incorporate an age-related effect; however, the effect was quite small relative to the climate effect. This can be illustrated by comparing median CRT between mature (100-200 years) and old (>200 years) stands occupying very dry $\left(\mathrm{CMI}_{\overline{\mathrm{wy}}}<-100 \mathrm{~cm} \mathrm{yr}^{-1}\right)$ and very wet $\left(\mathrm{CMI}_{\overline{\mathrm{wy}}}>100 \mathrm{~cm} \mathrm{yr}^{-1}\right)$ areas. Median CRT differed by $6 \%$ (16 vs. 17 years) between mature and old stands in very dry areas and by $10 \%$ (47 vs. 52 years) in very wet areas. Conversely, median CRT of mature stands differed $98 \%$ (16 vs. 47 years) between very dry and very wet areas, while the median CRT of old stands differed $101 \%$ (52 vs. 17 years) between very dry and very wet areas. In other words, the difference in CRT between stands in contrasting climates is much greater than the difference in CRT between mature and old stands within the same climate zone. Our study demonstrates that CRT in live-tree biomass was strongly influenced by water availability. However, additional efforts are needed to determine the underlying mechanism by which changes in water availability affect CRT, particularly given that CRT is a primary source of uncertainty in global vegetation model projections of future terrestrial carbon cycling (Friend et al., 2014).

\subsection{Predicting ecosystem response to environmental change}

Water availability is projected to decline in much of the western US over the coming century, in part due to higher temperatures increasing atmospheric evaporative demand (Dai, 2013; Walsh et al., 2014; Cook et al., 2015). Predicting the timing, magnitude, and extent of ecological response to regional climate change remains a challenge. Our study showed that water availability is a key determinant of forest structure and function in the western US, broadly suggesting that chronic reductions in regional water availability could reduce the NPP, BIO, and CRT in mature stands. Nevertheless, it is problematic to predict the temporal response of extant forest communities to near-term climatic change based on bioclimatic relationships derived from spatial data. For instance, recent studies found that the slope of the NPP-precipitation relationship was much steeper when derived from spatial data than when derived from the temporal response of NPP to interannual variation in precipitation (Jin and Goulden, 2014; Wilcox et al., 2016). Nearterm effects of climate variability depend on the physiological characteristics of species in the extant plant community. However, bioclimatic relationships derived from spatial data reflect gradual adjustment of community composi- 
tion and population size to climate over long periods of time (Jin and Goulden, 2014; Wilcox et al., 2016). Furthermore, bioclimatic models derived from spatial data cannot account for other ecophysiological impacts of environmental change, such as (1) enhanced plant water use efficiency from $\mathrm{CO}_{2}$ fertilization (Soulé and Knapp, 2015), (2) increased likelihood of tree mortality due to hotter drought (Adams et al., 2009), or (3) novel changes in disturbance regimes (Dale et al., 2001; Hicke et al., 2006). Consequently, predicting ecological response to environmental change over the coming century will require the use of mechanistic ecosystem models that account for physiologic, demographic, and disturbance processes at fine taxonomic and spatial scales (Hudiburg et al., 2013; Law, 2014). Although spatial models may not be suitable for near-term projection of ecosystem change, they do provide insight into long-term ecosystem adaptation to local climate and, furthermore, can be used to validate and refine mechanistic models if constructed from a representative sample of forestland.

\subsection{Summary and conclusions}

Water availability varies widely across the western US, giving rise to forests that range from dry, low-biomass woodlands to temperate rainforests that are among the highest biomass forests found anywhere in the world. In this study we quantified changes in tree productivity, live biomass, and carbon residence time along spatial gradients in water availability using field inventory measurements from WAORCA and satellite remote sensing data sets spanning the western US. Our multi-method, multi-scale analysis revealed that tree productivity, live biomass, and carbon residence time all increased notably with water availability, which we computed using an index that accounted for both precipitation and reference evapotranspiration. The observed increase in productivity was likely due to the close coupling between carbon and water cycling on leaf-to-ecosystem scales, while the observed increase in live biomass was associated with higher productivity and longer carbon residence. The increase in carbon residence time in wetter areas was linked with greater carbon allocation to long-lived aboveground tissues, older stand age, and, possibly, lower biomass mortality rates from natural disturbances (e.g., bark beetles, fires). Tree productivity and biomass derived from field and satellite measurements exhibited similar responses to increasing water availability, though the satellite data sets tended to plateau in the wettest areas, suggesting that additional efforts are needed to better quantify productivity and biomass from satellites in high-productivity, high-biomass forests. The pronounced increase in tree productivity, biomass, and carbon residence time between the driest and wettest areas illustrates the gradual adjustment of ecosystem structure and function to long-term variation in water availability; however, the observed bioclimatic relationships are not suitable for nearterm projections of future ecosystem response to regional drying. Predicting near-term ecosystem response to drying and other environmental change (e.g., increased $\mathrm{CO}_{2}$ ) will require mechanistic ecosystem models, which can be evaluated against bioclimatic relationships developed using inventory sites from a representative sample of forestlands (e.g., Forest Service inventory sites). Overall, our results indicate that water availability is a key determinant of tree productivity, live biomass, and carbon residence time in mature stands ranging from dry woodlands to coastal temperate rainforests. Future efforts are needed to anticipate and mitigate the impacts of projected warming and drying on forest ecosystems in the western US and elsewhere around the world.

\section{Data availability}

The data sets that we used in this analysis are nearly all publicly available online. In particular, MODIS NPP are available from the Numerical Terradynamic Simulation Group at the University of Montana (NTSG, 2017; http://www.ntsg. umt.edu/project/mod17\#data-product) and MODIS LAI can be accessed using the NASA Reverb data portal (NASA, 2017; https://reverb.echo.nasa.gov/reverb/). The satellitederived biomass data sets are available from the Oak Ridge National Laboratory Distributed Active Archive Center for Biogeochemical Dynamics (ORNL DAAC, 2017; https:// daac.ornl.gov/) and the US Forest Service (USFS, 2017; https://www.fs.usda.gov/rds/archive/). The forest inventory data can be obtained from the USFS Forest Inventory and Analysis program (USFS FIA, 2017; https://www.fia.fs.fed. us/), while the derived estimates of forest biomass and productivity are available on request.

Author contributions. L. T. Berner designed the study, analyzed the data, and prepared the manuscript with contributions from B. E. Law and T. W. Hudiburg, who both also contributed data sets to this effort.

Competing interests. The authors declare that they have no conflict of interest.

Acknowledgements. This work was supported by NASA Headquarters under the NASA Earth and Space Science Fellowship Program (Grant NNX14AN65H), the USDA National Institute of Food and Agriculture (Grant 2013-67003-20652), and the ARCS Foundation Scholar program. T. W. Hudiburg was supported by the National Science Foundation Idaho EPSCoR Program (Grant IIA-1W301792). We thank Charles Bourque for serving as the handling associate editor for our paper and also thank the four anonymous reviewers for their constructive feedback.

Edited by: C. Bourque

Reviewed by: four anonymous referees 


\section{References}

Adams, H. D., Guardiola-Claramonte, M., Barron-Gafford, G. A., Villegas, J. C., Breshears, D. D., Zou, C. B., Troch, P. A., and Huxman, T. E.: Temperature sensitivity of drought-induced tree mortality portends increased regional die-off under globalchange-type drought, P. Natl. Acad. Sci. USA, 106, 7063-7066, doi:10.1073/pnas.0901438106, 2009.

Allen, R. G., Pereira, L. S., Raes, D., and Smith, M.: Crop evapotranspiration-Guidelines for computing crop water requirements-FAO Irrigation and drainage paper 56, FAO, Rome, Italy, 300 pp., 1998.

Ball, J. T., Woodrow, I. E., and Berry, J. A.: A model predicting stomatal conductance and its contribution to the control of photosynthesis under different environmental conditions, in: Progress in photosynthesis research, Springer, Providence, Rhode Island, USA, 221-224, 1987.

Bechtold, W. and Patterson, P.: The enhanced forest inventory and analysis program - national sampling design and estimation procedures, USDA Forest Service General Technical Report SRS80, Asheville, NC, USA, 98 pp., 2005.

Berner, L. T. and Law, B. E.: Water limitations on forest carbon cycling and conifer traits along a steep climatic gradient in the Cascade Mountains, Oregon, Biogeosciences, 12, 6617-6635, doi:10.5194/bg-12-6617-2015, 2015.

Berner, L. T. and Law, B. E.: Plant traits, productivity, biomass and soil properties from forest sites in the Pacific Northwest, 19992014, Scientific Data, 3, 160002, doi:10.1038/sdata.2016.2, 2016.

Berner, L. T., Beck, P. S. A., Loranty, M. M., Alexander, H. D., Mack, M. C., and Goetz, S. J.: Cajander larch (Larix cajanderi) biomass distribution, fire regime and post-fire recovery in northeastern Siberia, Biogeosciences, 9, 3943-3959, doi:10.5194/bg9-3943-2012, 2012.

Berner, L. T., Beck, P. S. A., Bunn, A. G., and Goetz, S. J.: Plant response to climate change along the forest-tundra ecotone in northeastern Siberia, Glob. Change Biol., 19, 3449-3462, doi:10.1111/gcb.12304, 2013.

Blackard, J., Finco, M., Helmer, E., Holden, G., Hoppus, M., Jacobs, D., Lister, A., Moisen, G., Nelson, M., and Riemann, R.: Mapping US forest biomass using nationwide forest inventory data and moderate resolution information, Remote Sens. Environ., 112, 1658-1677, 2008.

Cairns, M. A., Brown, S., Helmer, E. H., and Baumgardner, G. A.: Root biomass allocation in the world's upland forests, Oecologia, 111, 1-11, 1997.

Carroll, A. L., Sillett, S. C., and Kramer, R. D.: MillenniumScale Crossdating and Inter-Annual Climate Sensitivities of Standing California Redwoods, PLoS ONE, 9, e102545, doi:10.1371/journal.pone.0102545, 2014

Churkina, G. and Running, S. W.: Contrasting climatic controls on the estimated productivity of global terrestrial biomes, Ecosystems, 1, 206-215, 1998.

Collins, M., Knutti, R., Arblaster, J., Dufresne, J.-L., Fichefet, T., Friedlingstein, P., Gao, X., Gutowski, W. J., Johns, T., Krinner, G., Shongwe, M., Tebaldi, C., Weaver, A. J., and Wehner, M.: Long-term Climate Change: Projections, Commitments and Irreversibility, in: Climate Change 2013: The Physical Science Basis. Contribution of Working Group I to the Fifth Assessment Report of the Intergovernmental Panel on Climate Change, edited by: Stocker, T. F., Qin, D., Plattner, G.-K., Tignor, M., Allen, S. K., Boschung, J., Nauels, A., Xia, Y., Bex, V., and Midgley, P. M., Cambridge University Press, Cambridge, UK and New York, NY, USA, 1029-1136, 2013.

Cook, B. I., Ault, T. R., and Smerdon, J. E.: Unprecedented 21st century drought risk in the American Southwest and Central Plains, Science Advances, 1, e1400082, doi:10.1126/sciadv.1400082, 2015.

Dai, A.: Increasing drought under global warming in observations and models, Nature Climate Change, 3, 52-58, doi:10.1038/nclimate1633, 2013.

Dale, V. H., Joyce, L. A., McNulty, S., Neilson, R. P., Ayres, M. P., Flannigan, M. D., Hanson, P. J., Irland, L. C., Lugo, A. E., Peterson, C. J., Simberloff, D., Swanson, F. J., Stocks, B. J., and Michael Wotton, B.: Climate Change and Forest Disturbances, Bioscience, 51, 723-734, 2001.

Daly, C., Halbleib, M., Smith, J. I., Gibson, W. P., Doggett, M. K., Taylor, G. H., Curtis, J., and Pasteris, P. P.: Physiographically sensitive mapping of climatological temperature and precipitation across the conterminous United States, Int. J. Clim., 28, 2031-2064, 2008.

Dawson, T. E.: Fog in the California redwood forest: ecosystem inputs and use by plants, Oecologia, 117, 476-485, 1998.

Droogers, P. and Allen, R. G.: Estimating reference evapotranspiration under inaccurate data conditions, Irrigation and drainage systems, 16, 33-45, 2002.

Fischer, D. T., Still, C. J., Ebert, C. M., Baguskas, S. A., and Park Williams, A.: Fog drip maintains dry season ecological function in a California coastal pine forest, Ecosphere, 7, e01364, doi:10.1002/ecs2.1364, 2016.

Friedl, M. A., Sulla-Menashe, D., Tan, B., Schneider, A., Ramankutty, N., Sibley, A., and Huang, X.: MODIS Collection 5 global land cover: Algorithm refinements and characterization of new datasets, Remote Sens. Environ., 114, 168-182, 2010.

Friend, A. D., Lucht, W., Rademacher, T. T., Keribin, R., Betts, R., Cadule, P., Ciais, P., Clark, D. B., Dankers, R., and Falloon, P. D.: Carbon residence time dominates uncertainty in terrestrial vegetation responses to future climate and atmospheric $\mathrm{CO}_{2}, \mathrm{P}$. Natl. Acad. Sci. USA, 111, 3280-3285, 2014.

Gholz, H. L.: Environmental Limits on Aboveground Net Primary Production, Leaf Area, and Biomass in Vegetation Zones of the Pacific Northwest, Ecology, 63, 469-481, doi:10.2307/1938964, 1982.

Girardin, C. A. J., Malhi, Y., Aragao, L., Mamani, M., Huaraca Huasco, W., Durand, L., Feeley, K., Rapp, J., Silva-Espejo, J., and Silman, M.: Net primary productivity allocation and cycling of carbon along a tropical forest elevational transect in the Peruvian Andes, Glob. Change Biol., 16, 3176-3192, 2010.

Goetz, S. and Dubayah, R.: Advances in remote sensing technology and implications for measuring and monitoring forest carbon stocks and change, Carbon Management, 2, 231-244, doi:10.4155/cmt.11.18, 2011.

Goetz, S. J., Sun, M., Zolkos, S., Hansen, A., and Dubayah, R.: The relative importance of climate and vegetation properties on patterns of North American breeding bird species richness, Environ. Res. Lett., 9, 034013, doi:10.1088/1748-9326/9/3/034013, 2014.

Hargreaves, G. H. and Samani, Z. A.: Reference crop evapotranspiration from temperature, Appl. Eng. Agric., 1, 96-99, 1985. 
Hicke, J. A., Logan, J. A., Powell, J., and Ojima, D. S.: Changing temperatures influence suitability for modeled mountain pine beetle (Dendroctonus ponderosae) outbreaks in the western United States, J. Geophys. Res.-Biogeo. (2005-2012), 111, G02019, doi:10.1029/2005JG000101, 2006.

Hicke, J. A., Meddens, A. J., Allen, C. D., and Kolden, C. A.: Carbon stocks of trees killed by bark beetles and wildfire in the western United States, Environ. Res. Lett., 8, 035032, doi:10.1088/1748-9326/8/3/035032, 2013.

Hijmans, R. J. and van Etten, J.: Raster: Geographic analysis and modeling with raster data, 2.1-25 ed., R Foundation for Statistical Computing, Vienna, Austria. 2013.

Hogg, E., Brandt, J. P., and Kochtubajda, B.: Growth and dieback of aspen forests in northwestern Alberta, Canada, in relation to climate and insects, Can. J. Forest Res., 32, 823-832, 2002.

Hogg, E., Brandt, J., and Michaelian, M.: Impacts of a regional drought on the productivity, dieback, and biomass of western Canadian aspen forests, Can. J. Forest Res., 38, 1373-1384, 2008.

Hogg, E. H.: Climate and the southern limit of the western Canadian boreal forest, Can. J. Forest Res., 24, 1835-1845, 1994.

Hogg, E. H. and Hurdle, P.: The aspen parkland in western Canada: A dry-climate analogue for the future boreal forest?, Water Air Soil Pollut., 82, 391-400, 1995.

Holdridge, L. R.: Determination of World Plant Formations From Simple Climatic Data, Science, 105, 367-368, doi:10.1126/science.105.2727.367, 1947.

Hudiburg, T., Law, B., Turner, D. P., Campbell, J., Donato, D., and Duane, M.: Carbon dynamics of Oregon and Northern California forests and potential land-based carbon storage, Ecol. Appl., 19, 163-180, 2009.

Hudiburg, T. W., Law, B. E., Wirth, C., and Luyssaert, S.: Regional carbon dioxide implications of forest bioenergy production, Nature Climate Change, 1, 419-423, doi:10.1038/nclimate1264, 2011.

Hudiburg, T. W., Law, B. E., and Thornton, P. E.: Evaluation and improvement of the Community Land Model (CLM4) in Oregon forests, Biogeosciences, 10, 453-470, doi:10.5194/bg-10453-2013, 2013.

Jin, Y. and Goulden, M. L.: Ecological consequences of variation in precipitation: separating short-versus long-term effects using satellite data, Global Ecol. Biogeogr., 23, 358-370, 2014.

Johnstone, J. A. and Dawson, T. E.: Climatic context and ecological implications of summer fog decline in the coast redwood region, P. Natl. Acad. Sci. USA, 107, 4533-4538, 2010.

Keith, H., Mackey, B. G., and Lindenmayer, D. B.: Re-evaluation of forest biomass carbon stocks and lessons from the world's most carbon-dense forests, P. Natl. Acad. Sci. USA, 106, 1163511640, 2009.

Kellndorfer, J., Walker, W., LaPoint, E., Bishop, J., Cormier, T., Fiske, G., Hoppus, M., Kirsch, K., and Westfall, J.: NACP Aboveground Biomass and Carbon Baseline Data (NBCD 2000), USA, 2000 Data set, ORNL DAAC, Oak Ridge, Tennessee, USA, 2012.

Krankina, O. N., DellaSala, D. A., Leonard, J., and Yatskov, M.: High-Biomass Forests of the Pacific Northwest: Who Manages Them and How Much is Protected?, Environ. Manage., 54, 112$121,2014$.
Law, B. E.: Regional analysis of drought and heat impacts on forests: current and future science directions, Glob. Change Biol., 20, 3595-3599, doi:10.1111/gcb.12651, 2014.

Law, B. E., Thornton, P. E., Irvine, J., Anthoni, P. M., and Van Tuyl, S.: Carbon storage and fluxes in ponderosa pine forests at different developmental stages, Glob. Change Biol., 7, 755-777, 2001.

Law, B. E., Falge, E., Gu, L. V., Baldocchi, D. D., Bakwin, P., Berbigier, P., Davis, K., Dolman, A. J., Falk, M., and Fuentes, J. D.: Environmental controls over carbon dioxide and water vapor exchange of terrestrial vegetation, Agr. Forest Meteorol., 113, 97-120, 2002.

Law, B. E., Sun, O. J., Campbell, J., Van Tuyl, S., and Thornton, P. E.: Changes in carbon storage and fluxes in a chronosequence of ponderosa pine, Glob. Change Biol., 9, 510-524, 2003.

Major, J.: A climatic index to vascular plant activity, Ecology, 44, 485-498, 1963.

Means, J. E., Hansen, H. A., Koerper, G. J., Alaback, P. B., and Klopsch, M. W.: Software for computing plant biomassBIOPAK users guide, US Department of Agriculture, Forest Service, Pacific Northwest Research Station, Portland, OR, USA, 184 pp., 1994.

Mitchell, K. E., Lohmann, D., Houser, P. R., Wood, E. F., Schaake, J. C., Robock, A., Cosgrove, B. A., Sheffield, J., Duan, Q., and Luo, L.: The multi-institution North American Land Data Assimilation System (NLDAS): Utilizing multiple GCIP products and partners in a continental distributed hydrological modeling system, J. Geophys. Res.-Atmos., 109, D07S90, doi:10.1029/2003JD003823, 2004.

Myneni, R., Hoffman, S., Knyazikhin, Y., Privette, J., Glassy, J., Tian, Y., Wang, Y., Song, X., Zhang, Y., and Smith, G.: Global products of vegetation leaf area and fraction absorbed PAR from year one of MODIS data, Remote Sens. Environ., 83, 214-231, 2002.

Nakawatase, J. M. and Peterson, D. L.: Spatial variability in forest growth-climate relationships in the Olympic Mountains, Washington, Can. J. Forest Res., 36, 77-91, 2006.

NASA: MODIS LAI, available at: https://reverb.echo.nasa.gov/ reverb/, last access: 20 January 2017.

Neeti, N. and Kennedy, R.: Comparison of national level biomass maps for conterminous US: understanding pattern and causes of differences, Carbon Balance and Management, 11, 1-19, doi:10.1186/s13021-016-0060-y, 2016.

NTSG: MODIS NPPs, available at: http://www.ntsg.umt.edu/ project/mod17\#data-product, last access: 20 January 2017.

Olson, J. S.: Energy storage and the balance of producers and decomposers in ecological systems, Ecology, 44, 322-331, 1963.

ORNL DAAC: Satellite-derived biomass data sets, available at: https://daac.ornl.gov/, last access: 20 January 2017.

Pan, Y., Chen, J. M., Birdsey, R., McCullough, K., He, L., and Deng, F.: Age structure and disturbance legacy of North American forests, Biogeosciences, 8, 715-732, doi:10.5194/bg-8-7152011, 2011.

Peterman, W., Waring, R. H., Seager, T., and Pollock, W. L.: Soil properties affect pinyon pine-juniper response to drought, Ecohydrology, 6, 455-463, 2013.

R Core Team: R: A Language and Environment for Statistical Computing, R Foundation for Statistical Computing, Vienna, Austria, 2015. 
Ruefenacht, B., Finco, M., Nelson, M., Czaplewski, R., Helmer, E., Blackard, J., Holden, G., Lister, A., Salajanu, D., and Weyermann, D.: Conterminous US and Alaska forest type mapping using forest inventory and analysis data, Photogramm. Eng. Rem. S., 74, 1379-1388, 2008.

Ruehr, N. K., Law, B. E., Quandt, D., and Williams, M.: Effects of heat and drought on carbon and water dynamics in a regenerating semi-arid pine forest: a combined experimental and modeling approach, Biogeosciences, 11, 4139-4156, doi:10.5194/bg11-4139-2014, 2014.

Running, S. W.: Testing Forest-BGC Ecosystem Process Simulations Across a Climatic Gradient in Oregon, Ecol. Appl., 4, 238 247, 1994

Running, S. W., Nemani, R. R., Heinsch, F. A., Zhao, M., Reeves, M., and Hashimoto, H.: A continuous satellite-derived measure of global terrestrial primary production, Bioscience, 54, 547560,2004

Runyon, J., Waring, R., Goward, S., and Welles, J.: Environmental limits on net primary production and light-use efficiency across the Oregon transect, Ecol. Appl., 4, 226-237, 1994.

Sanford, W. E. and Selnick, D. L.: Estimation of Evapotranspiration Across the Conterminous United States Using a Regression With Climate and Land-Cover Data1, J. Am. Water Resour. As., 49, 217-230, 2013.

Schroeder, P. E., McCandlish, B., Waring, R. H., and Perry, D. A.: The relationship of maximum canopy leaf area to forest growth in eastern Washington, Northwest Sci., 56, 121-130, 1982.

Schuur, E. A.: Productivity and global climate revisited: the sensitivity of tropical forest growth to precipitation, Ecology, 84, 1165-1170, 2003.

Schwalm, C. R., Williams, C. A., Schaefer, K., Baldocchi, D., Black, T. A., Goldstein, A. H., Law, B. E., Oechel, W. C., and Scott, R. L.: Reduction in carbon uptake during turn of the century drought in western North America, Nat. Geosci., 5, 551556, 2012.

Smith, J. E., Heath, L. S., Skog, K. E., and Birdsey, R. A.: Methods for calculating forest ecosystem and harvested carbon with standard estimates for forest types of the United States, USDA Forest Service General Technical Report NE-343, Newtown Square, PA, USA, 222 pp., 2006.

Soulé, P. T. and Knapp, P. A.: Analyses of intrinsic water-use efficiency indicate performance differences of ponderosa pine and Douglas-fir in response to $\mathrm{CO}_{2}$ enrichment, J. Biogeogr., 42, 144-155, 2015.

Spies, T. A., Ripple, W. J., and Bradshaw, G.: Dynamics and pattern of a managed coniferous forest landscape in Oregon, Ecol. Appl., 4, 555-568, 1994.

Thomas, C. K., Law, B. E., Irvine, J., Martin, J. G., Pettijohn, J. C., and Davis, K. J.: Seasonal hydrology explains interannual and seasonal variation in carbon and water exchange in a semiarid mature ponderosa pine forest in central Oregon, J. Geophys. Res.-Biogeo., 114, G04006, doi:10.1029/2009JG001010, 2009.

US Forest Service: Satellite-derived biomass data sets, available at: https://www.fs.usda.gov/rds/archive/, last access: 20 January 2017.

US Forest Service Forest Inventory and Analysis: Forest inventory data, available at: https://www.fia.fs.fed.us/, last access: 20 January 2017
Van Tuyl, S., Law, B., Turner, D., and Gitelman, A.: Variability in net primary production and carbon storage in biomass across Oregon forests - an assessment integrating data from forest inventories, intensive sites, and remote sensing, Forest Ecol. Manag., 209, 273-291, 2005.

Walsh, J., Wuebbles, D., Hayhoe, K., Kossin, J., Kunkel, K., Stephens, G., Thorne, P., Vose, R., Wehner, M., Willis, J., Anderson, D., Doney, S., Feely, R., Hennon, P., Kharin, V., Knutson, T., Landerer, F., Lenton, T., Kennedy, J., and Somerville, R.: Our Changing Climate, in: Climate Change Impacts in the United States: The Third National Climate Assessment, edited by: Melillo, J. M., Richmond, T. C., and Yohe, G. W., US Global Change Research Program, 19-67, 2014.

Waring, R.: Estimating forest growth and efficiency in relation to canopy leaf area, Adv. Ecol. Res, 13, 327-354, 1983.

Waring, R. H. and Franklin, J. F.: Evergreen coniferous forests of the Pacific Northwest, Science, 204, 1380-1386, 1979.

Waring, R. H. and Running, S. W.: Forest Ecosystems: Analysis at Multiple Scales, 3rd ed., Elsevier Academic Press, Burlington, MA, USA, 420 pp., 2007.

Webb, W. L., Lauenroth, W. K., Szarek, S. R., and Kinerson, R. S.: Primary production and abiotic controls in forests, grasslands, and desert ecosystems in the United States, Ecology, 134-151, 1983.

Whittaker, R. H.: Estimation of net primary production of forest and shrub communities, Ecology, 42, 177-180, 1961.

Whittaker, R. H. and Niering, W. A.: Vegetation of the Santa Catalina Mountains, Arizona. V. Biomass, production, and diversity along the elevation gradient, Ecology, 56, 771-790, 1975.

Wickham, H. and Francois, R.: dplyr: A Grammar of Data Manipulation, $\mathrm{R}$ package version 0.4 .2 , available at: http://CRAN R-project.org/package=dplyr (last access: 20 November 2016), 2015.

Wilcox, K. R., Blair, J. M., Smith, M. D., and Knapp, A. K.: Does ecosystem sensitivity to precipitation at the site-level conform to regional-scale predictions?, Ecology, 97, 561-568, 2016.

Williams, A. P., Seager, R., Macalady, A. K., Berkelhammer, M., Crimmins, M. A., Swetnam, T. W., Trugman, A. T., Buenning, N., Noone, D., and McDowell, N. G.: Correlations between components of the water balance and burned area reveal new insights for predicting forest fire area in the southwest United States, Int. J. Wild. Fire, 24, 14-26, doi:10.1071/WF14023, 2014.

Williams, M., Rastetter, E., Fernandes, D., Goulden, M., Wofsy, S., Shaver, G., Melillo, J., Munger, J., Fan, S. M., and Nadelhoffer, K.: Modelling the soil-plant-atmosphere continuum in a Quercus-Acer stand at Harvard Forest: the regulation of stomatal conductance by light, nitrogen and soil/plant hydraulic properties, Plant Cell Environ., 19, 911-927, 1996.

Williams, M.: Deforesting the Earth: From Prehistory to Global Crisis, University of Chicago Press, Chicago, USA, 543 pp., 2006.

Wilson, B. T., Woodall, C., and Griffith, D.: Imputing forest carbon stock estimates from inventory plots to a nationally continuous coverage, Carbon balance and management, 8, 1-15, 2013.

Yan, K., Park, T., Yan, G., Liu, Z., Yang, B., Chen, C., Nemani, R. R., Knyazikhin, Y., and Myneni, R. B.: Evaluation of MODIS LAI/FPAR Product Collection 6. Part 2: Validation and Intercomparison, Remote Sensing, 8, G04006, doi:10.1029/2009JG001010, 2016. 
Yang, Y., Fang, J., Ma, W., and Wang, W.: Relationship between variability in aboveground net primary production and precipitation in global grasslands, Geophys. Res. Lett., 35, L23710, doi:10.1029/2008GL035408, 2008.

Zhao, M., Running, S., Heinsch, F. A., and Nemani, R.: MODISderived terrestrial primary production, in: Land Remote Sensing and Global Environmental Change: NASA's Earth Observing System and the Science of ASTER and MODIS, edited by: Ramachandra, B., Justice, C. O., and Abrams, M. J., Springer, New York, USA, 635-660, 2010.
Zotarelli, L., Dukes, M. D., Romero, C. C., Migliaccio, K. W., and Morgan, K. T.: Step by step calculation of the Penman-Monteith Evapotranspiration (FAO-56 Method), Institute of Food and Agricultural Sciences, University of Florida, FL, USA, 2010. 